\title{
The Role of Primary Health Care Toward Healthy Aging
}

\author{
Dhanasari Vidiawati, Yuda Turana, Tonny Sundjaya*
}

ABSTRACT

Background: According to the World Health Organization, healthy aging is the process of developing and maintaining functional abilities that make the elderly happy. The increase in the elderly population requires more attention. In particular, health services at the primary health care level face problems related to the limited capacity of overall health services, especially in terms of health promotion and preventive health issues. It is necessary to improve the quality of health care services for the elderly to prevent greater health problems among the elderly population.

Objectives: Understand the need to provide holistic health services for healthy aging and use their capabilities, and strengthen cooperation among health professionals in achieving healthy aging.

Discussion: Primary health care is pointed out that primary health care should provide comprehensive services in a holistic manner to support a healthy aging process. Therefore, a well-structured, integrated, and cross-industry collaborative primary care system is needed. The system should include changes in professional behavior, coordination of care, and participation of patients' families and communities in comprehensive health care. This can be achieved through inter-professional education, continuous training and education of primary health care professionals, as well as primary health care services and cross-level health care technology innovation.

Conclusions: Healthy aging is not just the absence of disease. Everyone in health and social care at all levels can play a role to help improve healthy aging. To make the elderly healthy, starting from the prevention of young health problems, it requires collaboration between health workers, primary health care and other health service levels, and health care that cooperates with patients, families, and communities.

Keywords: healthy aging, primary care, preventive, health worker

\author{
*Correspondent: \\ tonny.sundjaya@danone.com \\ Tonny Sundjaya \\ Danone Specialized Nutrition Indonesia
}

\section{INTRODUCTION}

The world is aging. As people's life expectancy increases and the number of children born decreases, the absolute number of elderly people is increasing. There are 600 million people over the age of 60 in the world; by 2025, the total will double. ${ }^{1}$ It is said that there are more elderly people in East Asia and the Pacific today than anywhere else in the world. ${ }^{2}$ In Indonesia, according to the data of Sensus Penduduk in 2020 conducted by Badan Pusat Statistik (BPS), the total elderly population in Indonesia has increased from $5.04 \%$ in 2010 to $5.95 \%$ in $2020^{3}$. In addition to the elderly age group, the Ministry of Health of the Republic of Indonesia also pays attention to the elderly age group (45-59 years old). In this group, people are committed to strengthening health, disease prevention and early detection of diseases. ${ }^{4,5}$

Longevity is a victory for public health and the result of social and economic development. However, the rapid growth of population aging is expected to continue to exceed the social and economic development of developing countries. With age, the risk of chronic diseases and disabilities increases. In order to prepare for unprecedented population aging, it is important to prepare health systems in developing countries to deal with the consequences of these demographic trends ${ }^{1}$.

\section{DISCUSSION}

\section{Healthy Aging and Primary Health Care}

Currently, health care is mainly focused on disease and treatment. In addition, the elderly and frail people express their unmet needs for daily work and happiness. Therefore, health care professionals, especially primary care workers, will face a shift in focus from treating diseases to promoting health (healthy aging). ${ }^{6}$ The classic definition of healthy aging proposed by Rowe and Khan is based on the balance between the following three factors: absence of disease and diseaserelated disabilities, high functional ability, and active participation in life. ${ }^{7}$

Ideally, primary care professionals, such as general practitioners, family physicians and practice nurses, should play a central role in overall population care. ${ }^{6}$ The attending physician usually initiates an assessment of the patient's potential problems. Using a holistic and comprehensive approach, primary care physicians can improve the recognition of common patient problems. These problems are not only physical problems, but also psychological and sociocultural problems. ${ }^{8}$ In addition, WHO starts from preventing any problems, and emphasizes the role of primary health care and the contribution of community health workers to maintaining 
the quality of life of the population, and emphasizes the importance of services that integrate various conditions. ${ }^{9}$

In addition to preventing health problems at the community level, primary care (PHC) is designated as a priority to assist and monitor the health of the local population. ${ }^{10}$ These PHC centers are also expected to provide ongoing management and care. Their ideal position is to provide elderly people with regular and long-term contact and continuous care to prevent or delay disability caused by chronic health conditions. ${ }^{10}$ However, some studies conducted to evaluate the care of the elderly in primary care institutions have shown that in addition to the importance of establishing a comprehensive care network for the health of the elderly from the ground up, there is a need to expand preventive measures and promote health. The frequency of such actions Not high and little change. Earlier age set by PHC service. ${ }^{11,12}$

In Indonesia, the purpose of elderly care is also specified under Regulation No. 67 of 2015 of the Minister of Health of the Republic of Indonesia, which arranges for Puskesmas (government primary health center) to provide elderly care services. ${ }^{4}$ By 2020 , Indonesia will have 10.134 Puskesmas and more than 38.400 private PHCs. Although both agencies follow government regulations to manage the plan, the private $\mathrm{PHC}$ seems to be less affected by the government.

Puskesmas, as one of the PHC service agencies, provides health care services to the elderly and the elderly, including promotion, prevention, treatment and rehabilitation. Health services for the elderly include health improvement, health education, early detection of daily activity disorders or health problems, regular physical examinations, disease treatment and health recovery. Elderly health services include overall evaluation of the elderly, healthy elderly health services and elderly patient health services. ${ }^{13}$ Indonesia has an integrated guidance post called "Pos Pembinaan Terpadu" (Pos Pembinaan Terpadu) that has been implemented, which includes early detection of adult health and health education. However, some studies have found that the current Posbindu plan cannot effectively prevent and control adult health. ${ }^{14,15}$

Every country has regulations to protect the health of the elderly. For example, in India, the National Health Care Plan for Elderly (NPHCE) deals with the regulations on healthcare for the elderly. One of NPHCE's vision is to provide accessible, affordable, high-quality long-term, comprehensive and specialized care services for the aging population. The specific goals of NPHCE include easy access to promotion, prevention, treatment and rehabilitation services through a community-based PHC approach. The strategy to achieve this goal is based on a community-based PHC approach, including residence visits by trained medical staff and specialized services at the $\mathrm{PHC} /$ Community Health Center ( $\mathrm{CHC}$ ) level. ${ }^{16}$ In Brazil, the Ministry of Health issued the "Guidelines for Primary Health" (first edition) in 2007. 19. Instruct the primary care team to better address the needs of the elderly. They cover the promotion and prevention actions carried out by the PHC as one of the health services involved to achieve active and healthy aging, manage chronic non-communicable diseases
(CNCD) and build networks. ${ }^{9}$ Interestingly, both of these plans show limited information on services for the elderly population and fail to prepare for healthy aging, as shown in the Indonesia plan.

\section{Measurement of Healthy Aging}

Currently, the World Health Organization states that healthy aging is the process of developing and maintaining functional capabilities that can make the elderly healthy, but there is no other reference standard to evaluate healthy aging. This measurement method should reflect the concept, reach an agreement on how to achieve it, and then determine specific measures, problems, assessments, etc.; in each life stage of the entire life process, these measurement results should yield valid and reliable results, suitable for purpose. ${ }^{17}$ According to the definition of three areas, some predictive indicators of healthy aging are proposed, such as good health self-assessment, functional ability and perception of meaning in life.$^{18}$

\section{Interprofessional Education and Collaboration in supporting Healthy Aging}

It is necessary to establish a well-structured and fully integrated primary health care system to change professional behaviors, especially in the areas of preventive care, health care coordination, and communication with the elderly and seniors and other professionals. ${ }^{19}$ The behavior of professionals, including physicians, nurses, dentists, etc., is inseparable from the education of professionals. However, the primary and secondary education courses for professionals are not suitable for the necessary ability education of the elderly professionals, because these courses mainly focus on disease-related skills. ${ }^{6}$ Changing professional behaviors and starting to fully integrate and coordinate wellprepared old-age care requires inter-vocational education (IPE). ${ }^{6}, 19$ There is evidence that IPE can enhance the capabilities of professionals, which will lead to improved quality of healthcare and improved patient prognosis.6,20 Therefore, the true cooperation between inter-professional teams is the goalkeeper to break the "isolated" thinking in healthcare and provide care for an inclusive, comprehensive and holistic nursing culture that begins before the elderly. ${ }^{21}$

In Indonesia, the IPE program has been implemented in many universities, such as Sebelas Maret University (UNS) ${ }^{22}$, Diponegoro University ${ }^{23}$, University of Indonesia24, and Atma Jaya Catholic University of Indonesia ${ }^{25}$ etc. Research by Susanti et al. After studying the application of IPE among mothers and children in Leuwigajah PHC class, mothers' attitudes towards infant health increased. The results show that in the community of mothers' toddler classrooms, research on IPE through lectures, discussions, and on-site practice, student health workers can improve mothers' attitudes towards infant health. ${ }^{26}$ UNS conducted a study to determine the results of inter-professional, medical and midwife students based on the public perception of health services using the community-based IPE learning method in Sangkrah PHC. The community found that health services through inter-professional education are effective. Through public awareness, through the implementation of patient- 
centered care, and good communication between the medical team and patients and their families, and between members of the medical team, good medical care can be obtained through the implementation of good IPE. ${ }^{23}$ Based on these data, we believe that IPE can increase healthy aging preparation through the PHC program.

\section{Miscellaneous tools for empowering primary health care towards healthy aging}

One of the most important obstacles to health care is the lack of trained health care providers. Training is related to attitudes and skills, and is directly related to the quality of care provided and the outcome of care. ${ }^{1}$ Therefore, PHC employees must be continuously trained and educated to improve their ability in healthy aging services. Activities may include case discussions and meetings with relevant care providers or disciplines to fully manage patients with complex needs. ${ }^{27}$ Healthy aging requires continuous commitment and action by national leaders to develop evidence-based policies, as well as the training and education of healthcare personnel that can strengthen and support an active aging population. ${ }^{28,29}$

Healthcare innovations targeting the elderly (adults) can also help improve the sustainability of primary care for elderly healthcare services ${ }^{30}$ For example, the development of digital medical technology, such as wearable health trackers, can improve patient prognosis by increasing treatment compliance and timely access to medical services. Or expand the application and advancement of mobile technology (such as augmented reality) to help increase participation in health promotion. ${ }^{28,31,32}$ Recently, the elderly have the ability to take advantage of advances in information and communication technology. Four out of ten elderly people use mobile phones. Although the proportion of elderly people accessing the Internet is only $7.94 \%$, this number has continued to increase since 2015 (1.39\%) as we enter the Industrial Revolution era $4.0^{3}$ In addition, we recommend focusing on digital methods to support older age groups who are more familiar with digitization and mainly used in daily life. This is one of the efforts to prepare for healthy aging.

As the population ages, the incidence of noncommunicable diseases (NCD) including hypertension, metabolic syndrome, ischemic heart disease, stroke and diabetes continues to rise..$^{2,32}$ In Indonesia, some community empowerment programs for the prevention and control of non-communicable diseases are organizing health promotion activities under the "Cerdik and Patuh" plan. The "Cerdik" program is a preventive measure designed to enable healthy and healthy people to avoid taking various NCDs. The plan includes routine physical examinations, not smoking, physical exercise, a balanced diet, adequate rest and stress control. A "Patuh" plan was developed for patients with non-communicable diseases so that the disease does not worsen and the health status is under control. The plan includes routine physical examinations, proper treatment of diseases, balanced diet, adequate rest, stress control, safe physical exercise, and avoidance of smoking and drinking alcohol. $33,34,35 \mathrm{~A}$ systematic review in Indonesia shows that the "Cerdik" program can effectively improve the control of noncommunicable diseases, ${ }^{33}$ so it is very helpful to promote healthy aging. In addition, these activities can also be implemented well as digital participation materials in medical innovation. ${ }^{2}$

\section{Healthy Aging and cultural point of view}

The literature shows that not only the elderly themselves, but their families and culture also promote healthy aging. In other words, healthy aging is a multidimensional and complex concept, and there are substantial differences between different cultures..$^{36}$ In Indonesia, it is generally believed that parents will raise and take care of their children from infant to adulthood. Therefore, it is expected that children will take care of their parents during aging. As seen in Thailand ${ }^{36}$, In Indonesia, this connection can also be described as an obligation and a social norm. Research shows that different cultures lead to different successful aging. For example, Javanese youth believe that successful elderly people are those who live with their families, are willing to help others, lead a peaceful life and continue to engage in social and religious activities. Madurese culture claims that Islamic identity is very important, so job opportunities are regarded as the grace of God, so work will be carried out wholeheartedly until aging. In Nias, it is believed that the elderly in the family are becoming counselors and are respected by all members of the family and the community. Therefore, children and their offspring always take good care of them. ${ }^{37,38}$ Nurman Ahmad's research on the elderly and culture in Indonesia suggests that families must provide support for the elderly. The family should adjust the situation according to the wishes of the elderly. ${ }^{38}$ Therefore, it is strongly recommended that healthy aging care in primary care encourages those key figures who influence family beliefs and behaviors based on family culture to develop comprehensive health management to promote healthy aging before adults enter old age.

\section{CONCLUSION}

The world health system has not yet been prepared for the elderly, but everyone at all levels from basic research to advanced geriatrics technology, from first-line medical institutions to tertiary hospitals, regardless of their health and social care levels, has the potential to help improve the health of the elderly effect. people. The challenges facing health promoters include achieving better results in people's healthy lifestyle promotion before the elderly get older, and a positive attitude towards the health promotion of the elderly. It is necessary to provide adult-oriented practices through primary health care services to understand the needs of aging and to cooperate so that individuals can reach old age independently, autonomously and productively.

\section{ACKNOWLEDGEMENT}

The author would like to acknowledge the funding contribution of Sari Husada for the publication for this article. 


\section{REFERENCE}

1. Organization, W. H. Towards age-friendly primary health care. (World Health Organization, 2004).

2. Arensberg, M. B. Population aging: opportunity for business expansion, an invitational paper presented at the Asia-pacific economic cooperation (APEC) international workshop on Adaptation to population aging issues, july 17, 2017, Ha Noi, Viet Nam. J. Heal. Popul. Nutr. 37, 7 (2018).

3. Statistik, B. P. Badan pusat statistik. Badan Pus. Stat. (2017).

4. Mindianata, P. Faktor-faktor yang berpengaruh terhadap niat keaktifan lansia dalam mengikuti Posyandu Lansia. J. Promkes Indones. J. Heal. Promot. Heal. Educ. 6, 213-226 (2018).

5. Data, P. Informasi Kementerian Kesehatan Republik Indonesia. Situasi Lansia Di Indonesia Tahun 2017 Indonesia Gambar Struktur Umur Penduduk Indonesia Tahun 2017. Anal. Lansia di Indones. 2017 1, (2017).

6. Oeseburg, B. et al. Interprofessional education in primary care for the elderly: a pilot study. $B M C$ Med. Educ. 13, 1-7 (2013).

7. Rowe, J. W. \& Kahn, R. L. Successful aging. Gerontologist 37, 433-440 (1997).

8. Jahan, F. The Role of Primary Care Physician in Geriatric Care. Divers. Equal. Heal. care 13, 245 (2016).

9. Cucinotta, D. Preparing for the Decade of Healthy Aging (2020-2030): prevention plus therapy? Acta Bio Medica Atenei Parm. 89, 145 (2018).

10. Placideli, N. et al. Evaluation of comprehensive care for older adults in primary care services. Rev. Saude Publica 54, 6 (2020).

11. Tracy, C. S., Bell, S. H., Nickell, L. A., Charles, J. \& Upshur, R. E. G. The IMPACT clinic: Innovative model of interprofessional primary care for elderly patients with complex health care needs. Can. Fam. Physician 59, e148-e155 (2013).

12. Ruikes, F. G. H. et al. The CareWell-primary care program: design of a cluster controlled trial and process evaluation of a complex intervention targeting community-dwelling frail elderly. BMC Fam. Pract. 13, 1-9 (2012).

13. Statistik, B. P. Statistik penduduk lanjut usia 2014. Jakarta Badan Pus. Stat. (2015).

14. Alfiyah, A. \& Pujiyanto, P. an Analysis on the Implementation of the Integrated Guidance Post (Posbindu) Activities for Non-Communicable Diseases At Bogor City in 2018. J. Indones. Heal. Policy Adm. 4, (2019).

15. Rahadjeng, E. \& Nurhotimah, E. Evaluasi pelaksanaan posbindu penyakit tidak menular (Posbindu PTM) di lingkungan tempat tinggal. J. Ekol. Kesehat. 19, 134-147 (2020).

16. Verma, R. \& Khanna, P. National program of health-care for the elderly in India: A hope for healthy ageing. Int. J. Prev. Med. 4, 1103 (2013).

17. Michel, J.-P. \& Sadana, R. "Healthy aging" concepts and measures. J. Am. Med. Dir. Assoc. 18, 460-464 (2017).
18. Sowa, A., Tobiasz-Adamczyk, B., Topór-Mądry, R., Poscia, A. \& La Milia, D. I. Predictors of healthy ageing: public health policy targets. BMC Health Serv. Res. 16, 441-453 (2016).

19. Van Campen, C. Frail older persons in the Netherlands. (2011).

20. Fleck, F. Japan renews primary health care to promote healthy ageing. World Heal. Organ. Bull. World Heal. Organ. 96, 448-449 (2018).

21. Gougeon, L., Johnson, J. \& Morse, H. Interprofessional collaboration in health care teams for the maintenance of communitydwelling seniors' health and well-being in Canada: a systematic review of trials. J. Interprofessional Educ. Pract. 7, 29-37 (2017).

22. Toman, K. P., Probandari, A. N. \& Timor, A. B. Interprofessional education (IPE): luaran masyarakat terhadap pelayanan kesehatan dalam praktik kolaborasi di fakultas kedokteran. Nexus Pendidik. Kedokt. dan Kesehat. Univ. Sebel. Maret 5, 1-9 (2016).

23. Kristina, T. N. et al. Community-based healthprofessions interprofessional education: a collaborative and sustainable model. J. Pendidik. Kedokt. Indones. Indones. J. Med. Educ. 7, 46-53 (2018).

24. Sari, S. P. et al. Indonesian health professions students' perceptions toward an interprofessional education program: Findings after five years of implementation. Makara J. Heal. Res. 24, 6 (2020).

25. Triana, N. Interprofessional Education Di Institusi dan Rumah Sakit. (Deepublish, 2018).

26. Susanti, D., Wulandari, H., Juaeriah, R. \& Dewi, S. P. Penerapan interprofessional education (IPE) pada Kelas ibu balita oleh mahasiswa tenaga kesehatan untuk meningkatkan sikap ibu terhadap kesehatan balita di kota Cimahi. J. Sist. Kesehat. 3, (2017).

27. Chen, C. Y., Gan, P. \& How, C. H. Approach to frailty in the elderly in primary care and the community. Singapore Med. J. 59, 240 (2018).

28. Hedrich, W., Tan, J., Chalmers, B. \& Yeo, J. Advancing Into the Golden Years-Cost of Healthcare for Asia Pacific'S Elderly. US Marsh McLennan Co. (2016)

29. (WHO), W. H. O. Age-friendly primary health care centres toolkit. 2008. (2017).

30. Richard, E. et al. Healthy ageing through internet counselling in the elderly: the HATICE randomised controlled trial for the prevention of cardiovascular disease and cognitive impairment. BMJ Open 6, (2016).

31. Helbostad, J. L. et al. Mobile health applications to promote active and healthy ageing. Sensors 17, 622 (2017).

32. Kämpfen, F., Wijemunige, N. \& Evangelista, B. Aging, non-communicable diseases, and old-age disability in low-and middle-income countries: a challenge for global health. (2018).

33. Trisnowati, H. Pemberdayaan masyarakat untuk pencegahan faktor risiko penyakit tidak menular (studi pada pedesaan di Yogyakarta). 
(Hasanuddin University, 2018).

34. Hariawan, H. \& Pefbrianti, D. CERDIK Meningkatkan Pengendalian Penyakit Tidak Menular di Indonesia: Systematic Review. 2-TRIK TUNAS-TUNAS Ris. Kesehat. 10, 16-20 (2020).

35. Rahmadani, R. \& Sutarso, J. Strategi Promosi Kesehatan Puskesmas Colomadu II dalam Mensosialisasikan Perilaku Hidup Bersih dan Sehat (PHBS) Kepada Masyarakat. (2019).

36. Manasatchakun, P., Roxberg, Å. \& Asp, M. Conceptions of healthy aging held by relatives of older persons in Isan-Thai culture: A phenomenographic study. J. Aging Res. 2018, (2018).

37. Putri, I. SUCCESSFUL AGING PADA LANSIA (Studi Pada Lansia Dengan Budaya Jawa dan Madura). (2017).

38. Achmad, N. PERLAKUAN BUDAYA TERHADAP LANSIA (Studi Kasus Kehidupan Lansia Batak Karo, di Desa Lingga Sumatera Utara). in Seminar Nasional Hasil Penelitian \& Pengabdian Kepada Masyarakat (SNP2M) (2018). 